\title{
PENGARUH SIFAT GELAP PEMIMPIN TERHADAP NIAT KELUAR KERJA KARYAWAN
}

\author{
Giovani Anggasta Susantoํㅜ Achmad Sudjadi², Margani Pinasti ${ }^{3}$ \\ ${ }^{1}$ Magister Manajemen, FEB Unsoed, Indonesia \\ 2 Jurusan Manajemen, FEB Unsoed, Indonesia \\ 3 Jurusan Akuntansi, FEB Unsoed, Indonesia \\ Correspondence author: achmad.sudjadi@unsoed.ac.id
}

\begin{abstract}
ABSTRAK
Penelitian ini bertujuan untuk menganalisis pengaruh leader's dark triad traits (narcissism, Machiavellianism, dan psychopathy), abusive supervision, dan kepuasan kerja terhadap niat keluar kerja karyawan (turnover intention). Penelitian ini dilakukan di perusahaan penyedia barang promosi, Jakarta. Sebanyak 68 karyawan staff diminta untuk menilai tiga sifat kepribadian dan abusive supervision atasan langsungnya, serta evaluasi diri mengenai turnover intention dan kepuasan kerja melalui kuesioner online. Metode analisis dalam penelitian ini menggunakan Partial Least Square (PLS). Hasil analisis menunjukkan bahwa leader's dark triad traits kecuali leader's narcissism berpengaruh positif terhadap abusive supervision; hanya leader's psychopathy yang berpengaruh negatif terhadap kepuasan kerja dan positif terhadap turnover intention; abusive supervision tidak berpengaruh terhadap turnover intention, namun berpengaruh negatif terhadap kepuasan kerja; kepuasan kerja berpengaruh negatif terhadap turnover intention. Dapat disimpulkan bahwa psychopathy merupakan sifat kepribadian pemimpin yang paling merugikan organisasi karena memicu karyawan untuk meninggalkan perusahaan.
\end{abstract}

Kata kunci: leader's dark triad traits, abusive supervision, kepuasan kerja, niat keluar kerja karyawan.

\begin{abstract}
This study aims to investigate the influence of leader's dark triad traits (narcissism, machiavellianism, and psychopathy), abusive supervision, and job satisfaction on employees' turnover intention. The research was conducted in a company providing promotional gifts, Jakarta. Sixty-eight staff in the company assessed by using online questionnaire contain three personality traits and abusive supervision of their immediate leaders, turnover intention and job satisfaction. Partial Least Square (PLS) was used to analyse the data. The result shows that leader's dark triad traits except leader's narcissism had a positive effect on abusive supervision; only leader's psychopathy had a negative effect on job satisfaction and positive effect on turnover intention; abusive supervision did not significantly affect turnover intention, but had a negative effect on job satisfaction; job satisfaction had a negative effect on turnover intention. These might be concluded that, psychopathy is the most detrimental leader's personality trait of an organization because it can trigger employees to leave the organization.
\end{abstract}

Key words: leader's dark triad traits, abusive supervision, job satisfaction, turnover intention.

\section{PENDAHULUAN}

Banyak penelitian kepemimpinan hanya mempelajari sisi positif kepemimpinan dan dampaknya pada perilaku positif anak buah (Yukl, 2010), padahal ada juga pemimpin yang berperilaku negatif. Mempelajari sifat negatif pemimpin menjadi penting supaya dapat mengetahui dampaknya bagi anak buah dan bagi organisasi. Kepemimpinan adalah proses mempengaruhi anak buah untuk bekerja sesuai yang diharapkan dalam rangka mencapai 
tujuan organisasi (Bryman, 1992). Pemimpin dengan sifat dan perilakunya berupaya untuk mempengaruhi anak buah untuk mencapai tujuan organisasi, namun belum tentu sesuai dengan harapan anak buahnya. Menurut "teori pertukaran sosial" (Homans, 1959), dalam perilaku sosial kepemimpinan, perilaku pemimpin akan diimbangi dengan perilaku anak buah. Bila pemimpin memiliki sifat atau perilaku posisif, anak buah kemungkinan akan bekerja dengan baik, namun bila sifat atau perilaku pimpinannya negatif, bagaimana anak buah kemungkinan berperilaku?. Dengan demikian persepsi anak buah terhadap sifat atau perilaku pimpinannya sangat penting dalam kepemimpinan, karena sikap negatif pimpinan dapat memicu perilaku negatif anak buah.

Salah satu perilaku negatif karyawan adalah keinginan berpindah (turnover intention) yang dapat berdampak negatif pada organisasi. Keinginan berpindah dapat berkembang menjadi keputusan karyawan untuk benar-benar meninggalkan organisasi (actual turnover). Jika keinginan untuk keluar tersebut berasal dari dalam diri karyawan itu sendiri dan bukan merupakan keinginan organisasi, maka dapat mengganggu kegiatan organisasi. Secara empiris, tingkat turnover di berbagai organisasi masih tergolong tinggi, seperti dalam survei Hay Group (2013) yang memprediksi bahwa turnover rate secara global dari tahun 2012 hingga 2018 akan mengalami peningkatan yang signifikan dari 20,6\% sampai $23,4 \%$, sedangkan di Indonesia mencapai $26 \%$ di tahun 2014. Salah satu faktor yang mempengaruhi turnover intention dan perlu mendapat perhatian ialah sifat kepribadian pemimpin. Survei jobStreet.com melaporkan bahwa 53\% karyawan tidak puas dengan pekerjaannya karena buruknya karakter pemimpin atau atasan. Bahkan, gagal atau menyimpangnya kepemimpinan terletak pada personality disorder dari pemimpinnya (Hogan dan Hogan, 2001).

Terdapat tiga sifat kepribadian gelap pemimpin yang disebut dengan dark triad traits, yaitu narcissism, Machiavellianism, dan psychopathy (Paulhus dan Williams, 2002). Beberapa perilaku yang sering ditunjukkan oleh para pemimpin ini, antara lain mereka senang mengejek dan merendahkan karyawan, berbohong, manipulatif dan eksploitatif yang membuktikan bahwa mereka itu "beracun" (Mathieu et al., 2014). Sifat dan perilaku ini diindikasikan sebagai antiseden dari abusive supervision yang merupakan salah satu bentuk counterproductive work behavior (Mathieu dan Babiak, 2016). Abusive supervision didefinisikan sebagai persepsi bawahan akan perilaku kejam atasan mereka, baik verbal maupun non-verbal secara terus menerus, namun tidak termasuk kontak fisik. Bawahan yang merasa bahwa atasannya abusive, cenderung menunjukkan tingkat turnover intention dan turnover yang lebih tinggi (Tepper, 2000). 
Penelitian ini dilakukan di sebuah perusahaan penyedia barang jadi, khususnya dalam bidang promotion gifts yang telah berdiri sejak tahun 1991 di Jakarta. Selama empat tahun terakhir, turnover rate terus meningkat bahkan melebih target perusahaan, yaitu 5\%. Penelitian ini merupakan pengembangan dari penelitian sebelumnya tentang pengaruh corporate psychopathy, abusive supervision dan job satisfaction terhadap turnover intention oleh Mathieu dan Babiak (2016). Penelitian ini menambahkan dua variable independen, yaitu narcissism dan Machiavellianism yang merupakan dimensi dari dark triad traits. Beberapa penelitian telah menginisiasi studi tentang dark triad traits di negara dengan budaya kolektif, namun jumlahnya masih sangat terbatas (O'Boyle et al., 2012). Penelitian tentang fenomena ini masih tergolong baru di Indonesia yang menganut budaya collectivism dan high power distance dilihat dari minimnya publikasi penelitian. Berdasarkan latar belakang yang dipaparkan di atas, penelitian ini akan berfokus pada analisis pengaruh leader's dark triad traits, abusive supervision, job satisfaction terhadap turnover intention.

\section{TELAAH PUSTAKA DAN PENGEMBANGAN MODEL PENELITIAN}

\section{Definisi Variabel}

Terdapat enam variabel dalam penelitian ini, yaitu: Turnover intention ialah penilaian atau estimasi subjektif seseorang bahwa dia mungkin akan bertahan atau meninggalkan organisasi tempat dia bekerja (Mobley, 1982). Kepuasan kerja ialah suatu perasaan positif seseorang terhadap pekerjaannya yang merupakan hasil evaluasinya terhadap karakteristik pekerjaan tersebut (Robbins dan Judge, 2008). Abusive supervision ialah persepsi bawahan terhadap sejauh mana supervisor atau atasan mereka menunjukkan perilaku kejam, baik verbal maupun non-verbal secara terus menerus, namun tidak termasuk kontak fisik (Tepper, 2000). Leader's narcissism ialah sifat kepribadian pemimpin yang sangat mencintai diri sendiri dan cenderung memandang orang lain lebih rendah dari dirinya (Morf dan Rhodewait, 2001). Leader's Machiavellianism ialah sifat kepribadian pemimpin yang memiliki bakat alam untuk mempengaruhi orang lain demi kepentingan pribadinya, dan secara nyata menyalahgunakan kekuasaanya dalam wewenang resmi organisasi yang terlihat dalam perilakunya yang dominan (Goldberg, 1999 dalam Judge et al., 2009). Leader's psychopathy sifat kepribadian pemimpin yang menunjukkan sikap antisosial dan negatif terhadap orang lain (Hodson et al., 2009).

\section{Pengembangan Model Penelitian}

\section{Leader's Dark Triad Traits dan Abusive Supervision}


Socioanalytic theory menyatakan bahwa ketiga dimensi dark triad memiliki ciri-ciri yang memampukan mereka untuk "get ahead" atau selalu ingin lebih unggul dari orang lain (Hogan, 1983, 1996 dalam Judge et al., 2009). Hal ini membuat mereka dapat melakukan apapun termasuk perilaku abusive. Abusive supervision merupakan salah satu bentuk dari counterproductive work behavior (CWB). O’Boyle et al. (2012) melaporkan bahwa ketiga dimensi dark triad personalities secara signifikan berkaitan positif dengan CWB. Dengan demikian dark triad personalities berkaitan dengan abusive supervision.

Pemimpin yang sifat narsismenya tinggi memiliki self-esteem yang berlebihan (Bushman dan Baumeister, 1998). Mereka cenderung memandang kritik dan penghinaan dari orang lain sebagai ancaman terhadap ego mereka, sehingga akan lebih mengalami kemarahan dan CWB (Spector, 2011). Individu dengan Machiavellianism yang tinggi akan cenderung memanipulasi dan mengekploitasi orang lain (House dan Howell, 1992) dan tidak terlalu terbeban untuk menaati syarat-syarat normatif dari pertukaran sosial yang adil dalam kaitannya dengan CWB (O'Boyle et al., 2012). Pemimpin psikopat tidak peduli akan kewajiban sosial, hubungan timbal balik, dan tidak peka terhadap hak orang lain, sehingga dapat membuat mereka lebih mungkin untuk terlibat dalam CWB, seperti bullying (O’Boyle et al., 2012). Dengan demikian, hipotesis dalam penelitian ini adalah:

Hipotesis 1a: Leader's narcissism berpengaruh signifikan terhadap abusive supervision.

Hipotesis 1b: Leader's Machiavellianism berpengaruh signifikan terhadap abusive supervision.

Hipotesis 1c: Leader's psychopathy berpengaruh signifikan terhadap abusive supervision.

\section{Leader's Dark Triad Traits dan Kepuasan Kerja}

Pemimpin yang narsis tidak mempertimbangkan kebutuhan dan keinginan bawahannya, arogan, serta berpusat pada diri sendiri (Roshental dan Pittinsky, 2006), sehingga berpengaruh negatif terhadap kepuasan kerja bawahannya. Shurden (2015) menemukan bahwa ada efek tidak langsung dari pemimpin yang narsis dengan ketidakpuasan kerja karyawan, melalui leader-member exchange.

Pemimpin Machiavellianism senang memanipulasi dan mengeksploitasi bawahan untuk mencapai tujuan pribadinya (Rauthmann, 2012). Oleh karena itu, pemimpin dengan sifat ini akan cenderung tidak memperhatikan kebutuhan bawahannya. Menurut Gkorezis et al. (2015), pemimpin dengan sifat ini membuat bawahannya menjadi skeptis dan negatif terhadap organisasi, yang pada akhirnya mengalami kelelahan emosi. 
Penelitian dari Mathieu et al. (2014) menemukan bahwa penilaian bawahan terhadap sifat psikopat atasannya memprediksi tekanan psikologis, work family conflict, dan ketidakpuasan kerja. Mathieu dan Babiak (2015) melaporkan bahwa sifat psikopat yang dimiliki oleh pemimpin akan membuat bawahan mengalami ketidakpuasan kerja, motivasi kerja yang rendah, tekanan psikologi, dan turnover intention. Jadi, diasumsikan bahwa sifat psychopathy dan Machiavellianism pada pemimpin secara negatif berkaitan dengan kesejahteraan karyawan, karena pemimpin yang memiliki nilai tinggi pada kedua sifat ini cenderung secara ceroboh mengejar tujuan egoisnya dan tidak mempertimbangkan kebutuhan bawahan.

Hipotesis 2a: Leader's narcissism berpengaruh signifikan terhadap kepuasan kerja. Hipotesis 2b: Leader's Machiavellianism berpengaruh signifikan terhadap kepuasan kerja.

Hipotesis 2c: Leader's psychopathy berpengaruh signifikan terhadap kepuasan kerja.

\section{Leader's Dark Triad Traits dan Tunover Intention}

Pemimpin dengan sifat narsisme cenderung angkuh, berpusat pada diri sendiri, entitlement, dan kejam (Rosenthal dan Pittinsky, 2006). Mereka cenderung memandang orang lain lebih rendah dari dirinya sendiri dan seringkali tidak sensitif, bersikap kasar dan melebih-lebihkan diri sendiri. Dalam jangka panjang, orang yang narsis cenderung kesulitan untuk menjaga hubungan interpersonal yang baik dimana mereka kurang percaya dan perhatian terhadap orang lain (Morf dan Rhodewait, 2001). Para pemimpin Machiavellian menunjukkan rendahnya kejujuran dan kerendahan hati (Lee dan Ashton, 2005), memaksimalkan kepentingan diri dengan cara menipu dan merendahkan orang lain. Pemimpin dengan sifat ini ketika berinteraksi dengan orang lain menunjukkan sikap eksploitatif dan emosi yang dingin (Volmer et al., 2016). Penelitian dari Mathieu dan Babiak (2016) menunjukkan bahwa sifat psikopat seorang pemimpin mempengaruhi turnover intention secara langsung. Ciri-ciri psikopat dari supervisor adalah prediktor yang baik dari sikap negatif karyawan, khususnya niat untuk berhenti. Bawahan yang dihadapkan pada ketiga sifat pemimpin ini akan merasa tidak dihargai dan hubungannya dengan atasan menjadi renggang, sehingga dapat memicu niat mereka untuk berhenti dari pekerjaannya.

Hipotesis 3a: Leader's narcissism berpengaruh signifikan terhadap turnover intention. Hipotesis 3b: Leader's Machiavellianism berpengaruh signifikan terhadap turnover intention.

Hipotesis 3c: Leader's psychopathy berpengaruh signifikan terhadap turnover intention. 


\section{Abusive Supervision dan Tunover Intention}

Berdasarkan justice theory, ada tiga macam keadilan yang seharusnya diterima oleh subordinate, yaitu distributive justice, procedural justice, dan interactional justice. Apabila bawahan tidak merasa diperlakukan secara adil oleh atasannya maka mereka akan menganggap abusive supervision sebagai sumber ketidakadilan yang pada akhirnya berdampak kepada perilaku dan kesejahteraan mereka (Mirowsky dan Ross, 1989 dalam Tepper, 2000). Ketika subordinate merasa bahwa atasannya abusive, mereka akan mengalami tingkat stress dan tekanan yang tinggi serta menunjukkan perilaku yang tidak menyenangkan, yang pada akhirnya membuat mereka cenderung menunjukkan tingkat intention to quit dan turnover yang lebih tinggi. Hal ini sejalan dengan teori pertukaran sosial (Blau, 1964 dalam Wang et al., 2012) bahwa individu saling memberikan timbal balik di tempat kerja. Ketika mereka menerima perlakuan yang baik dari atasan atau merasa diuntungkan maka mereka akan membalasnya dengan perilaku yang baik pula. Sebaliknya, apabila karyawan merasa bahwa atasannya berperilaku negatif atau mengancam kesejahteraan mereka di tempat kerja, maka mereka akan cenderung bereaksi negatif.

Hipotesis 4: Abusive supervision berpengaruh signifikan terhadap turnover intention.

\section{Abusive Supervision dan Kepuasan Kerja}

Salah satu konsekuensi abusive supervision ialah ketidakpuasan kerja karyawan (Tepper, 2000). Hal ini sesuai dengan salah satu prinsip utama social exchange theory, yaitu reciprocity, baik positif maupun negatif. Menurut teori ini, dalam sebuah hubungan kerja yang saling berkaitan, apabila atasan memperlakukan bawahan dengan buruk maka akan ada ketidakseimbangan yang memicu bawahan untuk berperilaku negatif dan memberikan balasan berupa perilaku yang tidak menyenangkan pada organisasi dan agen organisasi, yaitu atasan (Cropanzano dan Mitchell 2005). Namun, jika perlakuan dari atasannya baik, maka pada umumnya hubungan antara bawahan dengan atasan akan cenderung positif. Hubungan yang baik antara supervisor dan bawahannya secara positif berkaitan dengan tingkat kepuasan kerja karyawan. Ketika karyawan memiliki hubungan yang baik dengan supervisornya, maka mereka cenderung puas dengan pekerjaannya dan mau berkontribusi untuk kemakmuran organisasi, karena mereka memandang supervisor sebagai wakil organisasi (Eisenberger et al., 2010).

Hipotesis 5: Abusive supervision berpengaruh signifikan terhadap kepuasan kerja. 


\section{Kepuasan Kerja dan Tunover Intention}

Dalam kaitannya dengan teori pertukaran sosial dimana prinsip utamanya adalah reciprocity atau timbal balik, maka seseorang dengan tingkat kepuasan kerja yang tinggi akan menunjukkan sikap positif terhadap pekerjaannya, sedangkan individu yang tidak puas memiliki sikap yang negatif. Kepuasan kerja secara positif mempengaruhi produktivitas, menurunkan tingkat ketidakhadiran, menurunkan tingkat turnover, mendukung tingkat kepuasan konsumen, mendukung OCB, dan membantu meminimalkan perilaku buruk di tempat kerja (Robbins dan Coulter, 2012).

Berdasarkan hierarchy of needs dari Abraham Maslow, beberapa faktor, seperti hubungan antar anggota organisasi, supervisi yang baik, adanya penghargaan dan pengakuan, serta aktualisasi diri, dapat menjadi parameter kepuasan kerja seseorang. Mobley et al. (1979) meneliti kepuasan kerja sebagai antiseden dari turnover intentions dan menemukan beberapa faktor yang dapat mempengaruhi turnover intention, yaitu job dissatisfaction. Kepuasan kerja merupakan prediktor yang signifikan dari turnover intentions dan berpengaruh negatif terhadap turnover intention (Kuo et al., 2014). Ini berarti bahwa semakin rendah kepuasan kerja individu atau semakin individu merasa tidak puas dengan pekerjaannya, maka niatnya untuk berhenti dari pekerjaan tersebut akan semakin tinggi.

Hipotesis 6: Kepuasan kerja berpengaruh signifikan terhadap turnover intention.

\section{METODE PENELITIAN}

\section{Responden dan Prosedur}

Karyawan staff sebuah perusahaan penyedia barang promosi diminta untuk berpartisipasi dalam penelitian ini dengan menyelesaikan serangkaian penilaian. Secara keseluruhan 74 karyawan staff diminta untuk menilai tiga sifat kepribadian dan abusive supervision atasan langsungnya, serta evaluasi diri mengenai turnover intention dan kepuasan kerja melalui kuesioner online. Sebanyak 16 atasan langsung dari berbagai divisi dinilai oleh karyawan staff yang dibawahinnya.

Penelitian ini merupakan sebagian dari sejumlah besar penelitian tentang kepribadian di tempat kerja dan berfokus pada kepribadian pemimpin. Pertama-tama peneliti meminta persetujuan responden untuk mengisi kuesioner dengan batas waktu pengumpulan selama dua minggu (14 hari). Survei online ini memakan waktu lebih kurang 15 menit untuk diisi. 


\section{Metode Pengukuran}

\section{Turnover Intention}

Turnover intention diukur dengan menggunakan instrumen yang diadaptasi dari Kelloway et al. (1999). Instrumen ini terdiri dari empat aspek utama sebagai berikut: 1) berpikir untuk meninggalkan organisasi; 2) berencana mencari pekerjaan baru; 3) berniat untuk bertanya kepada orang lain tentang peluang kerja baru; 4) tidak berencana untuk bertahan di organisasi ini lebih lama lagi. Jawaban responden diukur menggunakan 5-point Likert-type scale $(1=$ tidak pernah hingga $5=$ sangat sering).

\section{Kepuasan Kerja}

Kepuasan kerja akan diukur dengan menggunakan versi singkat dari Minnesota Satisfaction Questionnaire (MSQ) dari Weiss et al. (1967). Instrumen ini mencakup 20 aspek yang diukur dengan menggunakan 5-point Likert-type scale (1= sangat tidak puas hingga 5= sangat puas).

\section{Abusive Supervision}

Abusive supervision dapat diukur dengan menggunakan Abusive Supervision Scale dari Wulani et al. (2014). Pengukuran ini menggunakan 5-point Likert scale (1= tidak pernah hingga $5=$ sangat sering) dimana partisipan diminta untuk memberikan penilaian terhadap seberapa sering supervisor mereka terlibat di dalam 25 perilaku kunci.

\section{Leader's Dark Triad Traits}

Untuk mengukur kecenderungan dark triad traits yang dimiliki oleh immediatesupervisor, akan digunakan metode pengukuran yang disebut sebagai "The Dirty Dozen" yang diukur dengan 9-point Likert scales (1= sangat tidak setuju hingga 9= sangat setuju) dari Jonason dan Webster (2010). Metode ini merupakan metode ringkas dan mencakup 12 ciri-ciri dominan (dark sides) dari dark triad traits. Dimana masing-masing sifat diukur dengan empat ciri-ciri yang dominan.

\section{Teknik Analisis Data}

Dalam penelitian ini, program yang digunakan untuk mengolah data variabel atau data yang telah terkumpul ialah dengan software SmartPLS version 2.0 (Ghozali, 2008). PLS (Partial Least Square) merupakan analisis persamaan struktural (SEM) berbasis varian. Ada beberapa tahap dalam software ini, yaitu outer model atau model pengukuran untuk melihat hubungan antara indikator dengan konstruknya (validitas dan reliabilitas), inner model yaitu model struktural yang menghubungkan antar variabel laten ( $R$-square), dan uji bootstrapping untuk melihat hasil signifikansi (t-statistik dan $p$-value). Untuk pengujian hipotesis menggunakan nilai statistik dengan $\alpha=5 \%$, nilai t tabel yang yang digunakan 
adalah 1.96. Ukuran signifikansi keterdukungan hipotesis dapat digunakan perbandingan nilai $\mathrm{t}$ tabel dan $\mathrm{t}$ statistik. Jika t statistik > t-tabel, yaitu 1.96 berarti hipotesis diterima (Ghozali, 2008). Selain itu kriteria penerimaan atau penolakan hipotesis juga dapat ditunjukkan dengan $\mathrm{p}$-value. Jika p-value atau level signifikansi $\geq 0.05$, maka hipotesis ditolak. Sebaliknya, jika p-value $<0.05$, maka hipotesis diterima.

\section{HASIL PENELITIAN}

\section{Karakteristik Responden}

Dari 68 responden yang berpartisipasi dan menyelesaikan kuesioner, 41\% ialah pria $(\mathrm{n}=28)$ dan $59 \%$ wanita $(\mathrm{n}=40)$. Mayoritas usia responden berusia 25-26 tahun, yaitu sebesar 31\%. Sebanyak 60\% responden bekerja dalam rentang 1-3 tahun. Responden didominasi oleh lulusan sarjana (S1) sebesar 63\% dan belum menikah (57\%).

\section{Statistik Deskriptif}

Rata-rata jawaban responden untuk variabel leader's narcissism, leader's Machiavellianism, dan leader's psychopathy tergolong tinggi, yaitu sebesar 6.4025, 5.239, 5.074. Variabel abusive supervision dan kepuasan kerja memiliki nilai rata-rata jawaban responden sebesar 2.719 dan 2.907 yang tergolong moderat. Variabel turnover intention karyawan staff PT. Kusuma Megahperdana tergolong tinggi dengan rata-rata jawaban sebesar 3.493 .

\section{Analisis Data}

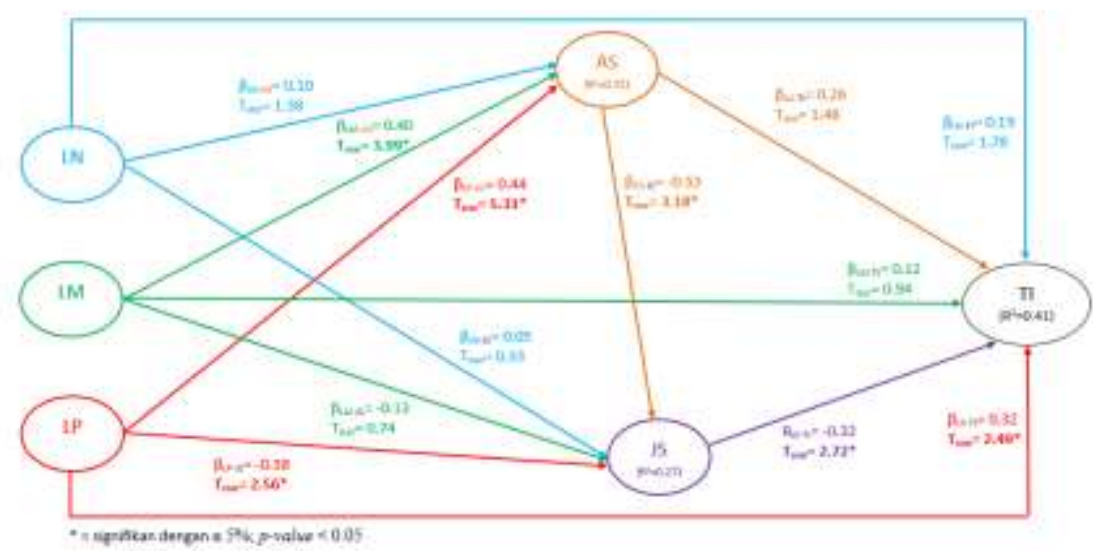

Gambar 4.1 Partial Least Square Model $(\mathrm{n}=68)$

Hasil analisis dilihat dari gambar 4.1 menunjukkan bahwa sebanyak enam hipotesis diterima dan enam hipotesis lainnya ditolak. Hipotesis 1a memiliki nilai t-statistik sebesar 
1.380, dimana nilai tersebut lebih rendah dari nilai t-tabel 1.96 namun lebih tinggi dari $p$ value 0.05. Dengan demikian hipotesis 1a bahwa leader's narcissism berpengaruh signifikan terhadap abusive supervision tidak terdukung atau hipotesis ditolak. Di sisi lain, hipotesis 1b bahwa leader's Machiavellianism berpengaruh signifikan terhadap abusive supervision terdukung dan pengaruhnya positif, dilihat dari nilai original sample 0.402 dan nilai tstatistik sebesar 3.987 yang lebih tinggi dari nilai t-tabel 1.96 serta lebih rendah dari $p$-value 0.05. Serupa dengan hal ini, hipotesis $1 \mathrm{c}$ memiliki nilai t-statistik di atas t-tabel 1.96, yaitu sebesar 5.314 dan di bawah p-value 0.05. Ini berarti bahwa leader's psychopathy berpengaruh signifikan terhadap abusive supervision dan pengaruhnya ialah positif, dengan nilai original sample 0.444 . Dapat disimpulkan bahwa hipotesis $1 \mathrm{~b}$ dan $1 \mathrm{c}$ didukung secara parsial, sedangkan hipotesis 1a tidak.

Hipotesis 2a dan 2b ditolak karena memiliki nilai t-statistik yang lebih rendah dibandingkan dengan nilai t-tabel 1.96, yaitu berturut-turut 0.333 dan 0.738 , serta lebih tinggi dari $p$-value 0.05. Ini berarti bahwa baik leader's narcissism maupun leader's Machiavellianism sama-sama tidak berpengaruh secara signifikan terhadap kepuasan kerja. Di sisi lain, hipotesis 2c bahwa leader's psychopathy berpengaruh signifikan terhadap kepuasan kerja diterima, dan pengaruhnya ialah negatif dengan nilai original sample - 0.378 dan nilai t-statistik sebesar 2.563732 lebih tinggi dari nilai t-tabel 1.96 serta lebih rendah dari $p$-value 0.05. Dengan demikian, hipotesis 2 didukung secara parsial, dimana hipotesis 2a dan $2 \mathrm{~b}$ ditolak, sedangkan hipotesis $2 \mathrm{c}$ diterima.

Hipotesis 3a dan 3b tidak didukung secara signifikan karena memiliki nilai t-statistik yang lebih rendah dibandingkan dengan nilai t-tabel 1.96, yaitu berturut-turut sebesar 1.782 dan 0.935 , serta lebih tinggi dari p-value 0.05. Ini berarti bahwa baik leader's narcissism maupun leader's Machiavellianism sama-sama tidak berpengaruh secara signifikan terhadap turnover intention. Di sisi lain, hipotesis 3c bahwa leader's psychopathy berpengaruh signifikan terhadap turnover intention terdukung dan pengaruhnya ialah positif. Hal ini dapat dilihat dari nilai original sample 0.318 dan nilai t-statistik sebesar 2.493 lebih tinggi dari nilai t-tabel 1.96 serta lebih rendah dari $p$-value 0.05. Dengan demikian, hipotesis 3 didukung secara parsial, dimana hipotesis 3a dan 3b ditolak, sedangkan hipotesis $3 c$ diterima.

Tidak ditemukan dukungan yang signifikan untuk hipotesis 4 yaitu mengenai pengaruh abusive supervision terhadap turnover intention. Ini ditunjukkan dengan nilai tstatistik yang lebih rendah dari nilai t-tabel 1.96, yaitu sebesar 1.479 serta lebih tinggi dari $p$-value 0.05. Hipotesis 5 yaitu bahwa abusive supervision berpengaruh signifikan terhadap kepuasan kerja terdukung dan pengaruhnya ialah negatif. Hal ini dapat dilihat dari nilai 
original sample - 0.529 dan nilai t-statistik sebesar 3.183 yang lebih tinggi dari nilai t-tabel 1.96 serta lebih rendah dari $p$-value 0.05 . Hipotesis 6 yang menyatakan bahwa kepuasan kerja berpengaruh signifikan terhadap turnover intention diterima dan pengaruhnya ialah negatif. Hal ini ditunjukkan dengan nilai original sample -0.316 dan nilai t-statistik sebesar 2.719, yang lebih tinggi dari nilai t-tabel 1.96 serta lebih rendah dari $p$-value 0.05 .

\section{PEMBAHASAN}

Penelitian ini menunjukkan bahwa sifat pemimpin (leader's traits - psychopath dan machiavelli) dapat memicu perilaku abusive terhadap anak buah yang menyebabkan ketidak puasan kerja dan keinginan untuk pindah kerja bagi karyawan. Namun, penelitian ini menunjukkan bahwa sifat narsis pemimpinnya tidak tidak dianggap abusive atau dianggap wajar oleh anak buah. Menurut Leary dan Kowalsky (1990) pemimpin yang narsis akan memodifikasi pola dan sifat interaksi dengan untuk menjaga kesan positif. Bila dilihat dari teori kekuasaan, pemimpin perusahaan ini sangat kuat, karena pemimpin tersebut adalah pucuk pimpinan dan pemilik perusahaan tersebut. Dengan kekuasaan yang dimiliki dan memperhatikan budaya "majikan -kuli" yang ada di perusahaan ini, maka sifat narsis dan machiavelli majikan, anak buah tidak dapat memprotesnya, keputusan akhir kalau karyawan tidak kuat melihat sifat dan perilaku pimpinan, kemungkinan adalah pindah kerja. Hal ini dapat diperkuat dengan argumen bahwa meskipun pimpinan bersifat narsis, nya

Sifat gelap pemimpin, terutama psychopathy - dapat juga menurunkan kepuasan kerja anak buah, namun sifat machiavellianism dan narsis dalam penelitian ini tidak mempengaruhi kepuasan kerja. Sifat psichopat meliputi antara lain mengakui hasil kerja karyawan sebagai hasil kerja pimpinan sendiri tanpa merasa bersalah, menyalahkan anak buah atas kesalahannya sendiri, tidak memedulikan bawahannya, dan tidak memiliki empati kepada anak buah. Hal ini menyebabkan anak buah mengalami kelelahan emosional yang akhirnya menyebabkan rendahnya kepuasan kerja anak buah. Seorang pemimpin yang mempunyai sifat machiavellianism senang memanipulasi dan mengekspoitasi anak buah untuk tujuan pribadinya, tetapi karena kepiawaiannya, anak buah tidak merasakannya, hal ini sesuai dengan penelitian terdahulu (Routhman, 2012., dan Jonason et al., 2012). Demikian halnya sifat narsis pemimpin tidak mempengaruhi kepuasan kerja anak buah. Hal ini memperkuat indikasi bahwa budaya "majikan - kuli" semakin jelas, meskipun nampak bahwa sifat pemimpinnya cenderung negatif terhadap kepuasan kerja, tetapi pengaruhnya terlihat bahwa sifat psikokat saja yang berpengaruh negatif terhadap 
kepuasan kerja. Jadi, bila pemimpinnya sudah keterlaluan, anak buah baru menganggap tidak memuaskan.

Selanjutnya, keinginan untuk keluar dari tempat kerja ini dipengaruhi oleh sifat pemimpin psikopat dan kepuasan kerja. Secara teoritis, baik sifat sifat negatif dan perilaku abusive pemimpin dan kepuasan kerja akan berpengaruh terhadap keinginan keluar. Tetapi hasil analisis menunjukan bahwa abusive supervision tidak berpengaruh terhadap keinginan keluar. Dengan demikian dapat disimpulkan bahwa sifat yang sangat kasar (psychopath) yang mempengaruhi munculnya abusive supervisin, rendahnya kepuasan kerja, dan turnover intention. Hal ini kemungkinan bahwa apabila suatu wilayah tingkat bargaining power tenaga kerja rendah karena lapangan kerja terbatas, maka kekuasaan majikan sangat dominan. Tenaga kerja akan susah mencari tempat bekerja yang baik, sehingga meskipun suasana kerja kurang kondusif, karyawan akan bertahan untuk tetap bekerja di perusahaan tersebut karena switching cost nya tinggi.

\section{KESIMPULAN DAN SARAN}

\section{Kesimpulan}

Leader's narcissism tidak berpengaruh signifikan terhadap abusive supervision. Ini berarti bahwa pemimpin dengan sifat ini dapat mengendalikan kesan positif orang lain terhadap diri mereka. Karyawan merasa bahwa sudah menjadi hal yang wajar jika seorang pemimpin menunjukkan sifat narsis. Dengan demikian, pemimpin yang narsis tidak dianggap memicu sikap abusive yang menjadi ancaman bagi karyawan. Leader's Machiavellianism berpengaruh positif signifikan terhadap abusive supervision. Pemimpin yang didominasi oleh sifat manipulatif, eksploitatif, dan senang merayu demi keuntungan pribadi dipandang olah karyawan sebagai pemimpin yang abusive. Leader's psychopathy berpengaruh positif signifikan terhadap abusive supervision. Pemimpin dengan sifat ini tidak peduli akan kewajiban sosial, hubungan timbal balik, dan tidak peka terhadap hak orang lain, sehingga sangat meresahkan karyawan dan dianggap sebagai pemicu dari sikap abusive pemimpin. Leader's narcissism tidak berpengaruh signifikan terhadap kepuasan kerja. Kepuasan kerja karyawan ternyata tidak tergantung dari sifat pemimpin yang berorientasi pada diri sendiri karena ia dipandang sebagai seorang yang karismatik bagi bawahannya. Leader's Machiavellianism tidak berpengaruh signifikan terhadap kepuasan kerja. Ini berarti bahwa sifat pemimpin ini tidak mempengaruhi kepuasan kerja karyawan karena pandai memanipulasi emosi bawahan. Ada kemungkinan bahwa kepuasan kerja mereka ditentukan oleh faktor lain diluar pemimpin yang tidak diteliti dalam penelitian ini yang membuat mereka dapat mentoleransi sifat pemimpin yang seperti ini. Leader's 
psychopathy berpengaruh negatif signifikan terhadap kepuasan kerja. Pemimpin yang didominasi oleh sikap antisosial ini dirasa sangat meresahkan dan sulit untuk ditoleransi. Hal ini membuat bawahan mengalami kelelahan emosional yang pada akhirnya mempengaruhi kepuasan kerja mereka. Leader's narcissism tidak berpengaruh signifikan terhadap turnover intention. Sifat pemimpin ini dianggap sebagai sesuatu yang wajar atau dapat ditolerir sehingga tidak mengganggu kinerja karyawan dalam organisasi.

Leader's Machiavellianism tidak berpengaruh signifikan terhadap turnover intention. Pemimpin dengan sifat ini seringkali menjilat bawahan, membujuk, serta memohon dengan berbagai macam alasan yang masuk akal. Namun demikian, karyawan masih bisa mentolerir dan menerimanya, serta tidak menjadikan mereka berniat untuk keluar kerja. Leader's psychopathy berpengaruh positif signifikan terhadap turnover intention. Sebagai dimensi dark triad yang paling berbahaya, tidak mengherankan bahwa pemimpin dengan sifat ini mempengaruhi niat karyawan untuk meninggalkan organisasi. Mereka sangat terganggu dengan pemimpin yang tidak memiliki empati atau rasa bersalah, tidak terlalu mempertimbangkan aspek moralitas dalam bertindak, tidak peka terhadap perasaan bawahannya, dan cenderung bersikap sinis. Abusive supervision tidak berpengaruh signifikan terhadap turnover intention. Dalam budaya kolektif dan jarak kekuasaan yang tinggi seperti Indonesia, abusive supervision dianggap sebagai hal yang normal dan dapat ditolerir sehingga tidak dapat menjadi prediktor langsung dari niat karyawan tersebut untuk berhenti dari organisasi. Abusive supervision berpengaruh negatif signifikan terhadap kepuasan kerja. Sikap abusive ini ditunjukkan dengan sikap seperti memperlakukan bawahan dengan tidak adil, meremehkan bawahan, tidak menghargai kerja keras bawahan, menunjukkan kemarahan tanpa alasan, dan sebagainya. Semakin karyawan tersebut merasa bahwa atasannya itu abusive, semakin rendah pula kepuasan kerja mereka. Kepuasan kerja berpengaruh negatif signifikan terhadap turnover intention. Semakin rendah kepuasan kerja individu, maka semakin tinggi niatnya untuk berhenti dari pekerjaan tersebut. Turnover intention ini diekspresikan dengan mulai mencari informasi tentang lowongan kerja baik secara online maupun bertanya kepada orang lain tentang peluang kerja baru.

\section{Keterbatasan Penelitian dan Penelitian Selanjutnya}

Penelitian ini dilakukan pada perusahaan skala menengah dan hanya di satu perusahaan sehingga sampel yang diambil dan jumlah pemimpin yang dinilai hanya sedikit. Fokus penelitian ini hanya pada dark side dari dark triad traits sehingga kurang dapat mengkaji bright side dari dark triad traits tersebut. Selain itu, instrumen yang dipakai untuk 
mengambil data dalam penelitian ini adalah kuesioner, sehingga jawaban yang didapat hanya terbatas pada pertanyaan yang tercantum dalam kuesioner. Penelitian ini terbatas pada penilaian karyawan terhadap pemimpin mereka, namun tidak dilakukan penilaian diri dari pemimpin maupun karyawan itu sendiri tentang sifat kepribadian mereka. Oleh karena itu, tidak dapat dilakukan pengukuran secara spesifik mengenai dark triad traits pada hubungan antara atasan dan bawahan.

Penelitian selanjutnya diharapkan dapat dilakukan pada beberapa perusahaan atau perusahaan skala besar yang memiliki jumlah karyawan dan pemimpin yang jauh lebih banyak dan beragam. Selain itu, bright side dari sifat dark triad sebaiknya juga dikaji supaya hasilnya dapat digunakan untuk memaksimalkan potensi pemimpin. Penelitian selanjutnya berkaitan dengan pengambilan data dapat dilakukan dengan metode wawancara mendalam sehingga akan didapatkan informasi lebih banyak dan luas atau mungkin bahkan variabel baru terkait dengan sifat pemimpin dalam organisasi. Diharapkan ada pengukuran yang lebih spesifik dan melibatkan pemimpin dan karyawan untuk menilai sifat kepribadian mereka sendiri.

\section{Saran}

Perusahaan sebaiknya lebih mempertimbangkan sifat kepribadian ketika melakukan seleksi dan perekrutan pimpinan secara ketat untuk mencegah seseorang dengan sifat psychopathy menduduki jabatan pemimpin yang tinggi. Misalnya dengan wawancara mendalam yang dilakukan oleh ahli psikologi dengan pertanyaan-pertanyaan yang tersirat namun dapat menggambarkan dengan jelas sifat kepribadian seseorang. Bagi pemimpin dengan sifat psychopathy yang telah menjabat di perusahaan, sebaiknya segera diberikan coaching dari pemimpin yang sudah berpengalaman dan memiliki karakter yang baik, agar mereka lebih berfokus pada bright side yang dimiliki dibandingkan dengan dark side yang merugikan perusahaan. Perusahaan harus memberikan sarana (conseling, laporan tertulis, atau formulir) bagi karyawan yang mengalami perilaku buruk dari pemimpinnya agar mereka berani untuk menyampaikan masalah atau pelanggaran yang dialami tanpa merasa takut dan tertekan.

\section{DAFTAR PUSTAKA}

Bryman, A. (1992). Charisma and leadership in organisations. London: Sage.

Bushman, B. J., A. M. Bonacci, W. C. Pedersen, E. A. Vasquez, and N. Miller. 2005. Chewing on It Can Chew You Up: Effects of Rumination on Triggered Displaced Aggression. Journal of Personality and Social Psychology. 88(6): 969-983. 
Cropanzano, R. dan M. S. Mitchell. 2005. Social Exchange Theory: An Interdisciplinary Review. Journal of Management. 31(6): 874-900.

Eisenberger, R., G. Karagonlar, F. Stinglhamber, P. Neves, T. E. Becker, M. Gonzalez- Morales, and M. Steiger-Mueller. 2010. Leader-Member Exchange and Affective Organizational Commitment: The Contribution of Supervisor's Organizational Embodiment. The Journal of Applied Psychology. 95(6): 1085- 1103.

Ghozali, I. 2008. Structural Equation Modeling Metode Alternatif dengan Partial Least Square (PLS). Edisi Dua. Badan Penerbit Universitas Diponegoro, Semarang.

Gkorezis, P., E. Petridou, and T. Krouklidou. 2015. The Detrimental Effect of Machiavellian Leadership on Employees' Emotional Exhaustion: Organizational Cynicism as a Mediator. Eur J Psychol. 11(4): 619-631.

Hay Group. 2013. Preparing for Take Off (Online), http://atrium.haygroup.com/ downloads/marketingps/in/Preparing\%20for\%20take\%20off_executive $\% 20$ summa ry_IN.pdf, diakses 10 Februari 2017.

Hodson, G., S. M Hogg, and C. C. MacInnis. 2009. The Role of 'Dark Personalities' (Narcissism, Machiavellianism, Psychopathy), Big Five Personality Factors, and Ideology in Explaining Prejudice. Journal of Research in Personality. 43: 686-690.

Hogan, R. and J. Hogan. 2001. Assessing Leadership: A View from the Dark Side. International Journal of Selection and Assessment. 9(1-2): 40-51.

Homans, George C. (1958) "Social Behaviour as Exchange." American Journal of Sociology 63, 6: 597-606.

House, R. J. and J. M. Howell. 1992. Personality and Charismatic Leadership. Leadership Quarterly. 3: 81-108.

Jonason, P. K. and G. D. Webster. 2010. The Dirty Dozen: A Concise Measure of The Dark Triad. Psychological Assessment. 22(2): 420-432.

Judge, T. A., J. A. LePine, and B. L. Rich. 2006. The Narcissistic Personality: Relationship with Inflated Self-Ratings of Leadership and with Task and Contextual Performance. Journal of Applied Psychology. 91: 762-776.

Judge, T. A., R. F. Piccolo, and T. Kosalka. 2009. The Bright and Dark Sides of Leader Traits: A Review and Theoretical Extension of the Leader Trait Paradigm. The Leadership Quarterly. 20: 855-875.

Kelloway, E. K., B. H. Gottlieb, and L. Barham. 1999. The Source, Nature, and Direction of Work and Family Conflict: A Longitudinal Investigation. Journal of Occupational Health Psychology. 4: 337-346.

Kuo, H. T., K. C. Lin, and I. C. Li. 2014. The Mediating Effects of Job Satisfaction on Turnover Intention for Long-Term Care Nurses in Taiwan. Journal of Nursing Management. 22: 225-233.

Lee, K. and M. C. Ashton. 2005. Psychopathy, Machiavellianism, and Narcissism in the FiveFactor Model and the HEXACO Model of Personality Structure. Personality and Individual Differences. 38: 1571-1582. 
Mathieu, C. and P. Babiak. 2016. Corporate Psychopathy and Abusive Supervision: Their influence on Employees' Job Satisfaction and Turnover Intentions. Personality and Individual Differences. 91: 102-106.

Mathieu, C. and P. Babiak. 2015. Tell Me Who You Are, I'll Tell You How You Lead: Beyond the Full-range Leadership Model, the Role of Corporate Psychopathy on Employee Attitudes. Personality and Individual Differences. 87: 8-12.

Mathieu, C., C. S. Neumann, R. D. Hare, and P. Babiak. 2014. A Dark Side of Leadership: Corporate Psychopathy and Its Influence on Employee Well-being and Job Satisfaction. Personality and Individual Differences. 59: 83-88.

Mobley, W. H. 1982. Some Unanswered Questions in Turnover and Withdrawal Research. Academy of Management Review. 7(1): 111 - 116.

Mobley, W. H., R. W. Griffeth, H. H. Hand, and B. M. Meglino. 1979. Review and Conceptual Analysis of the Employee Turnover Process. Psychological Bulletin. 86: 493-522.

Morf, C. C. and F. Rhodewait. 2001. Unraveling the Paradoxes of Narcissism: A Dynamic SelfRegulatory Processing Model. Psychological Inquiry. 12: 177-196.

O'Boyle, E. H., D. R. Forsyth, G. C. Banks, and M. A. McDaniel. 2012. A Meta-Analysis of the Dark Triad and Work Behavior: A Social Exchange Perspective. Journal of Applied Psychology. 97(3): 557.

Paulhus, D. L. and K. M. Williams. 2002. The Dark Triad of Personality: Narcissism, Machiavellianism, and Psychopathy. Journal of Research in Personality. 36: 556-563.

Rauthmann, J. F. 2012. Towards Multifaceted Machiavellianism: Content, Factorial, and Construct Validity of a German Machiavellianism Scale. Personality and Individual Differences. 52: 345-351.

Robbins, S. P and M. Coulter. 2012. Management. Eleventh Edition. Prentice Hall, New Jersey.

Robbins, S. P. dan T. A. Judge. 2008. Perilaku Organisasi. Buku Satu. Edisi 12. Diterjemahkan oleh Diana Angelica. Salemba Empat, Jakarta.

Rosenthal, S. A. and T. L. Pittinsky. 2006. Narcissistic Leadership. The Leadership Quarterly. 17: 617-633.

Shurden, S. B. 2015. Identifying the Effects of Narcissistic Leadership on Employee Job Satisfaction: A Study within The Accounting Profession. Doctoral dissertation. http://tigerprints.clemson.edu/all_dissertations/1329.

Spector. 2011. The Relationship of Personality to Counterproductive Work Behavior (CWB): An Integration of Perspectives. Human Resource Management Review. 21(4): 342-352.

Tepper, B. J. 2000. Consequences of Abusive Supervision. Academy of Management Journal. 43: 178-190.

Volmer, J., I. K. Koch, and A. S. Göritz. 2016. The Bright and Dark Sides of Leaders' Dark Triad Traits: Effects on Subordinates' Career Success and Well-Being. Personality and Individual Differences. 101: 413-418.

Yukl, G. (2010). Leadership in Organizations. Upper Saddle River: Pearson. 
Wang, W., J. Mao, W. Wu, and J. Liu. 2012. Abusive Supervision and Workplace Deviance: The Mediating Role of Interactional Justice and the Moderating Role of Power Distance. Asia Pacific Journal of Human Resources. 50(1): 43-60.

Weiss, D., R. Dawis, G. England, and L. Lofquist. 1967. Manual for the Minnesota Satisfaction Questionnaire, (Minnesota Studies on Vocational Rehabilitation, 22). Minneapolis University of Minnesota. Industrial Relations Center, Work Adjustment Project.

Wulani, F., B. M. Purwanto, dan H. Handoko. 2014. Abusive Supervision Scale Development in Indonesia. Gadjah Mada International Journal of Business. 16(1): 55-68. 